J. Clin. Chem. Clin. Biochem.

Vol. 17, 1979, pp. 15-21

\title{
Study of Sample Collection and Preparation Methods for Multi Element Analysis in Liver Tissue by Proton Induced X-Ray Emission (PIXE)
}

\author{
By B. Meinel, J. Ch. Bode.
}

Fachbereich Humanmedizin, Philipps-Universität Marburg/Lahn, W. Germany

W. Koenig and F. W. Richter

Fachbereich Physik, Philipps-Universität Marburg/Lahn, W. Germany

(Received March 31/August 1, 1978)

Summary: Large samples of tissue and biopsy specimen were taken from a single human liver, homogenized or paraffin-embedded, then analyzed by PIXE.

Homogenates, including those of biopsies, proved to be suitable for PIXE-analysis of $\mathrm{P}, \mathrm{S}, \mathrm{Ca}, \mathrm{Mn}, \mathrm{Fe}, \mathrm{Cu}, \mathrm{Zn}, \mathrm{Se}, \mathrm{Rb}$, $\mathrm{Mo}, \mathrm{Cd}$ and, to a limited extent, $\mathrm{Pb}$. Paraffin-embedding leads to a distinct elution of $\mathrm{K}, \mathrm{Rb}, \mathrm{Cl}$ and to a lesser elution of $\mathrm{P}, \mathrm{Zn}, \mathrm{Se}, \mathrm{Br}$ and $\mathrm{Mo}$. The contents of $\mathrm{Ca}$ and $\mathrm{Sr}$, on the other hand, were higher in the paraffin-embedded sections.

Sections of paraffin-embedded biopsies proved to be hardly suitable for PIXE-analysis.

\section{Untersuchungen zur Probennahme und Probenpräparation für die Spurenelementanalyse in Lebergewebe mittels protoneninduzierter Röntgenemission (PIXE)}

Zusammenfassung: Einer einzelnen menschlichen Leber wurden größere Gewebsproben und Biopsieproben entnommen, diese dann mit Standardverfahren homogenisiert oder in Paraffin eingebettet und anschließend auf Spurenelementgehalte analysiert.

Dabei erwiesen sich die Homogenate einschließlich der Biopsien für die hier verwendete Multielementanalyse zur Bestimmung von $\mathrm{P}, \mathrm{S}, \mathrm{Ca}, \mathrm{Mn}, \mathrm{Fe}, \mathrm{Cu}, \mathrm{Zn}, \mathrm{Se}, \mathrm{Rb}, \mathrm{Mo}, \mathrm{Cd}$ und - mit Einschränkung - von $\mathrm{Pb}$ als gut geeignet.

Paraffineinbettung führte besonders bei $\mathrm{K}, \mathrm{Rb}$ und $\mathrm{Cl}$, weniger hingegen bei $\mathrm{P}, \mathrm{Zn}, \mathrm{Se}, \mathrm{Br}$ und $\mathrm{Mo}$, zu einer Erniedrigung der Gehalte. Bei Ca und Sr wurden in den paraffinierten Proben dagegen höhere Gehalte gemessen. Schnitte von Paraffin-eingebetteten Biopsien erwiesen sich als kaum geeignet für Spurenelementbestimmung mittels PIXE.

\section{Introduction}

It has been reported that trace element analysis results are influenced by paraffin-embedding of the tissue $(1,2)$ and by sampling with steel needles (3): Thus, the reliability of biopsy specimens for trace element analysis was denied (3).

The purpose of our investigation was to determine the influence of different types of sample collection and of preparation techniques on specimen contamination and reproducibility of trace element analysis in liver samples.

In order to obtain information as to whether clinical standard techniques of tissue sampling and preparation can be used for multielement analysis, the following points were examined:

1. Effect of sampling with steel needles.

2. Influence of sample embedding, using the procedure for histological examination. In this respect, special attention was paid to the analysis of paraffin-embedded autopsy and biopsy samples stored in institutes of pathology (2).

\section{Materials and Methods}

All specimens analysed were taken from a single human liver belonging to the dissection material of the Marburg Institute of Pathology. The patient had died of asphyxia by alimentary 
bolus. Apart from signs compatible with chronic blood stasis duc to cardiac insufficiency, his liver did not show any pathological change.

\section{Collection and preparation of samples}

In order to determine the influence of different sampling procedures on the element content, the following methods were compared:

1. Pieces of tissue (average mass $0.8 \mathrm{~g}$ ) were cut about $1 \mathrm{~cm}$ below the capsule with a polystyrene knife (S IV, H I; legend as shown in table 1 ).

2. Biopsy specimens were taken with Menghini needles routinely used in diagnostic work. (Karl Storz KG, Tuttlingen, F. R. G.) (S II, H II).

3. Biopsy specimens were obtained by means of single use puncture needles "Hepafix-Punktionsnadel" (B. Braun, Melsungen, F. R. G.) (S III, H III).

For further preparation three alternative methods were employed:

\section{"Routine embedding"}

Paraffin-embedding by routine procedures for histological examinations. In this procedure the samples come into contact with a lot of metal tools and containers. (Autotechnicon model $2 \mathrm{~A}$, Swoads Company, Dublin, Ireland). Fixation in non-specifically cleaned solutions (S I). ("Paraffin für histologische Untersuchungen”, Riedel de Häen AG, Seelze/Hannover, F. R. G.).

\section{"Manual embedding"}

Manual paraffin-embedding, using solutions of low trace element content (p. a. quality, Merck) and avoiding any metal contact.

The paraffin-embedded samples were cut with a stainless steel microtome, floated on double distilled water and placed on a thin Formvar backing.

\section{Homogenisation}

Tissue specimens were diluted 1:10 in water double distilled in a quartz still, and homogenised in a Potter-Elvehjem-homogenisator (teflon/glass). The homogenates were stored at $-80^{\circ} \mathrm{C}$ in polystyrene tubes. A $10 \mu$ quantitiy of each sample was pipetted onto a Formvar backing and dried by infrared light.

Using the method described above seven groups of eight samples each were formed, as summarized in table 1.

Samples were taken from the ventral side of the right liver lobe as shown in figure 1. Biopsy specimens taken from neighbouring points were assigned in turn to the groups S I, S II, S III and H II, H III, in order to exclude systematic errors due to different sampling areas.

\section{Sam ple analy sis}

The trace element analysis was performed by proton-induced $\mathrm{X}$-ray emission (PIXE), which is described in detail elsewhere (4). The analysed sample mass (dry weight) was about 10-15 $\mu \mathrm{g}$ in the case of the biopsy sections S I-III, about $50 \mu \mathrm{g}$ for the large sections S IV and the homogenised biopsies H II-III, and $130 \mu \mathrm{g}$ for the homogenates $\mathrm{H} \mathrm{I}$. Both sections and homogenates

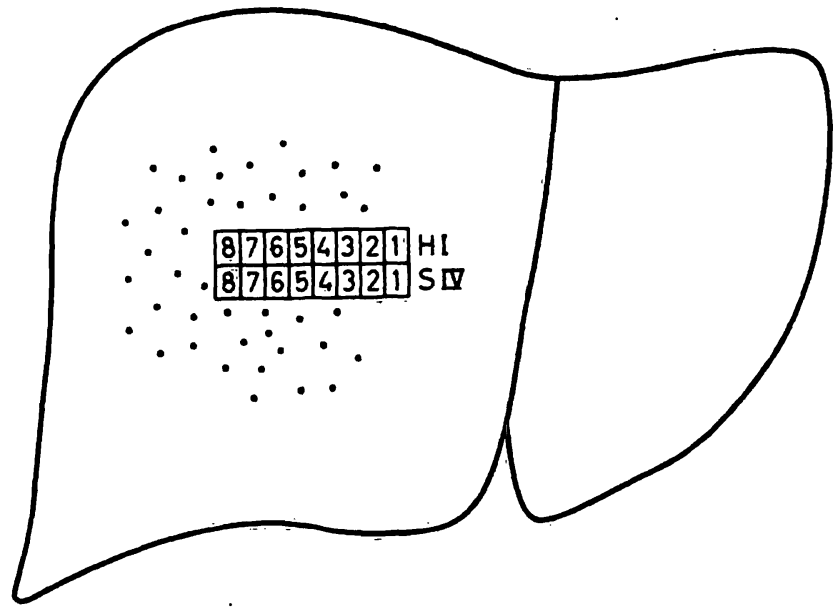

Fig. 1. Sampling points within the liver pieces of tissue $(0.8 \mathrm{~g}$, $\mathrm{H}$ : homogenates, S: sections)

biopsy samples (assigned in turn to the groups S I, S II, $\mathrm{S}$ III and H II, H III; for explanation see table 1).

were placed on Formvar foils of $2-5 \mu \mathrm{g} / \mathrm{cm}^{2}$ thickness. Foil contaminations with trace elements were negligible with respect to the sample. Also the distilled water was analysed directly from the still, and after applying the same preparative steps to it as to the real samples (e. g. homogenisation).

Contaminations due to the Formvar backing and the distilled water, which was added to the sample, were less than $1 \%$ of the trace element masses for all elements of the analysed liver samples.

The analysis of paraffin-contaminations by measuring the trace element content of the pure paraffin layer in a distance of some $\mathrm{mm}$ beside the liver sample was a failure, since the paraffin layer evaporates during the first seconds of exposure to the proton beam.

Because it was difficult to determine the sample mass directly by weighing, a special normalization method was performed, using the electron-Bremsstrahlungs-background in the X-ray spectrum (4). In this way, uncertainties in calculating the trace element contents, due to the inaccurately known masses of the analysed sample, were avoided.

The remaining uncertainties in the comparison of different sample groups are mainly due to

1. wash-out or contamination effects of elements such as $\mathrm{Na}$, $\mathrm{Cl}$ and $\mathrm{K}$, which are normally found in high concentrations within liver tissue and

2. to the mass of the remaining paraffin layer after exposure to the proton beam.

The influence of these effects on the calculated trace element contents is discussed in detail in l. c. (4) and (5); the resulting errors are estimated to be of the order of $10 \%-20 \%$ for the sample groups S I, S II, S III, less than $10 \%$ for the groups $\mathrm{S}$ IV, $\mathrm{H}$ II, H III and negligible for $\mathrm{H} \mathrm{I}$.

Tab. 1. Summary of the extraction and preparation techniques.

\begin{tabular}{|c|c|c|c|c|c|c|c|}
\hline Sample & Biopsy & Biopsy & Biopsy · & Piece of tissue & Piece of tissue & Biopsy & Biôpsy \\
\hline $\begin{array}{l}\text { Extraction } \\
\text { technique }\end{array}$ & $\begin{array}{l}\text { Menghini- } \\
\text { needle }\end{array}$ & $\begin{array}{l}\text { Menghini- } \\
\text { needle }\end{array}$ & $\begin{array}{l}\text { needle for } \\
\text { single use }\end{array}$ & $\begin{array}{l}\text { polystyrene } \\
\text { knife }\end{array}$ & $\begin{array}{l}\text { polystyrene } \\
\text { knife }\end{array}$ & $\begin{array}{l}\text { Menghini- } \\
\text { needle }\end{array}$ & $\begin{array}{l}\text { needle for } \\
\text { single use }\end{array}$ \\
\hline Preparation & $\begin{array}{l}\text { routine } \\
\text { embedding }\end{array}$ & $\begin{array}{l}\text { manual } \\
\text { embedding }\end{array}$ & $\begin{array}{l}\text { manual } \\
\text { embedding }\end{array}$ & $\begin{array}{l}\text { manual } \\
\text { embedding }\end{array}$ & $\begin{array}{l}\text { homogenisa- } \\
\text { tion }\end{array}$ & $\begin{array}{l}\text { homogenisa- } \\
\text { tion }\end{array}$ & $\begin{array}{l}\text { homogenisa- } \\
\text { tion }\end{array}$ \\
\hline Notation & S I & S II & S III & S IV & H I & H II & H III \\
\hline
\end{tabular}



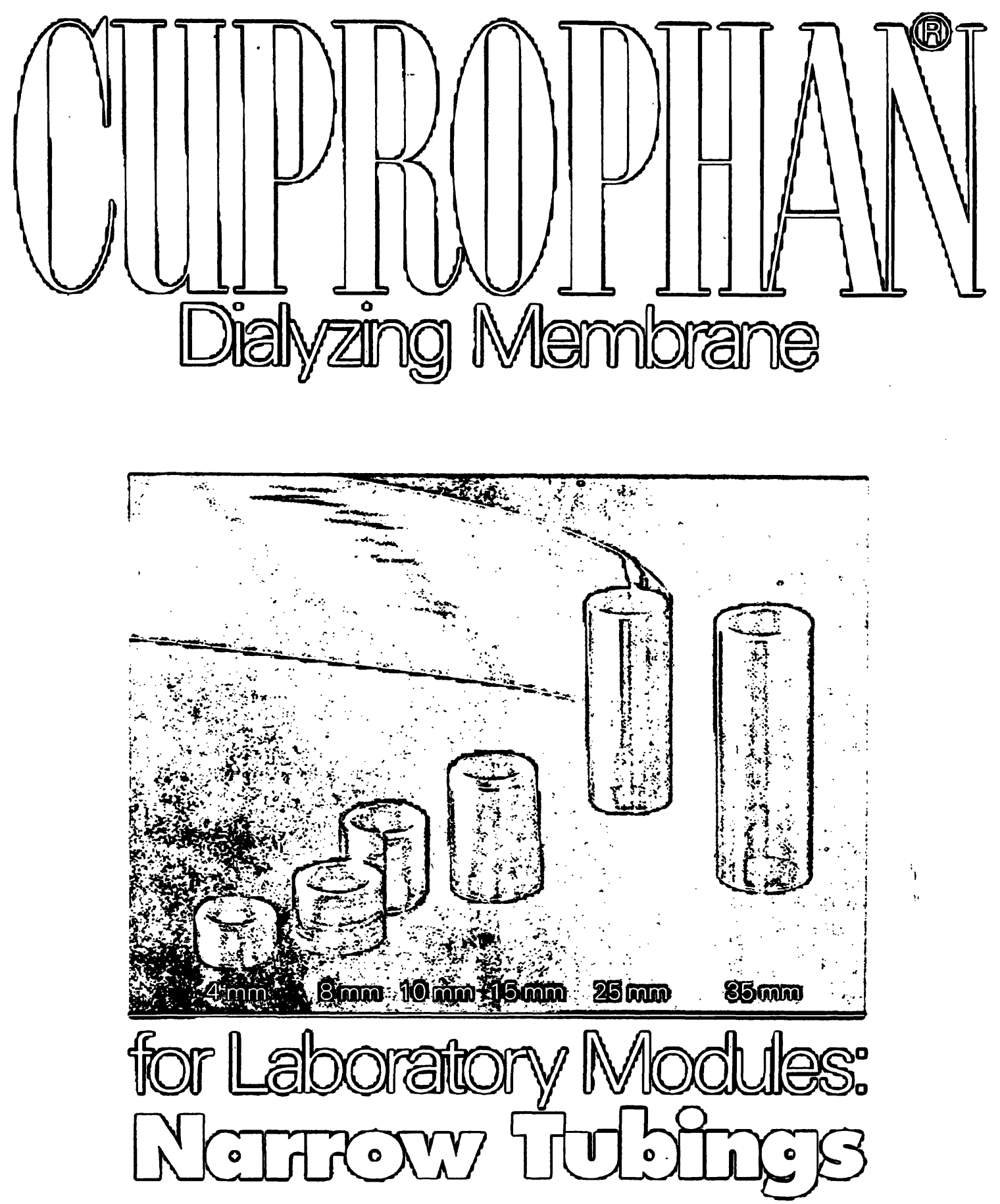

Cuprophan tubings - dry for your processing convenience are available also in lay flat widths of $4,8,10,15,25$, and $35 \mathrm{~mm}$. This semipermeable membrane may be used for separation processes of small samplings in laboratories.

Ask for samples and quotation.
Enka AG

Product Group

Dialyzing Membrane

Plant Wuppertal-Barmen P.O.B. 200916

D 5600 Wuppertal 2 W. Germany 


\begin{tabular}{ll}
\hline $\begin{array}{l}\text { Walter de Gruyter } \\
\text { of }\end{array}$ & $\begin{array}{l}\text { Wallin. New York } \\
\text { Ber }\end{array}$ \\
\hline
\end{tabular}

G. Kahl (Editor)

\section{Biochemistry of Wounded Plant Tissues}

Edited by Dr. Günter Kahl, Professor for Botany, Department of Biology, Johann Wolfgang Goethe University of Frankfurt am Main.

1978. $17 \mathrm{~cm} \times 24 \mathrm{~cm} .684$ pages. Hardcover DM 180.00 ISBN $311006801 \mathrm{X}$

This volume comprises original studies and survey articles by competent scientists from world-famous laboratories. It offers an overview of the present state of knowledge as regards the biochemistry and molecular biology of wound processes and woundhealing mechanisms as based on model systems from the plant kingdom. Extensive bibliographies of most recent literature are appended to each article, making the volume à rich source of information.

\section{Lamprecht}

\section{A. I. Zotin} (Editors)

\section{Thermodynamics of Biological Processes}

Edited by Dr. rer. nat. I. Lamprecht, Physicist, Professor for Biophysics, Free University Berlin, Institute for Biophysics, Berlin (West) and Dr. A. I. Zotin, Zoologist, Professor for Developmental Biology, Laboratory of Developmental Biophysics, N.K. Koltzov. Institute of Developmental Biology, Academy of Sciences of the USSR, Moscow.

$1978.17 \mathrm{~cm} \times 24 \mathrm{~cm} .448$ pages, 69 figures. Hardcover DM 180.00 ISBN 3110073129

Two groups of scientists from zoology, developmental biology and biophysics present an interesting application of the thermodynamics of non-linear irreversible processes to biological problems such as metabolism, development and aging. This monograph should lead to a deeper understanding of all these problems. 
To optimize the sensitivity in a larger region of atomic numbers $\mathrm{Z}$ two measurements with $2 \mathrm{MeV}$ and $4 \mathrm{MeV}$ protons were performed for each sample (5). Since the two runs at different proton energies are completely independent, they allow an additional check of accuracy; this is of special in terest because the errors discussed above are different in magnitude for the two runs. The differences between both measurements were about $5 \%$ for the sample groups S IV and H I - H III (homogenates). These variations are due to calibration uncertainties, and are therefore of a systematic nature. For biopsy sections the deviations between the two runs were larger (see fig. 4).

The calibration of the experiment was checked by a NBS bovine liver standard ${ }^{1}$ ). The agreement with the specified content is better than $20 \%$. Our measured contents are systematically too high for copper (ca. 10\%) and zinc (ca. $20 \%$ ) while for the other specified elements (K, Mn, Fe, Se, $\mathrm{Rb}, \mathrm{Cd}$ ) the differences are within the standard deviations. These differences seem to be due to calibration uncertainties, since they show a slow Z-dependence, which is unlikely in cases of contaminations.

\section{Results}

Trace element contents of analysed liver samples subjected to the different preparation methods are shown in figures $2 a$ and $2 b$. In addition, in figure 3 the copper content of all groups has been normalized to that of $\mathrm{HI}$ and the contents of all other elements were adapted correspondingly. Thus, the relative contents of different elements can be compared, while neglecting errors in calculating their absolute values. These relative contents show a much better correspondence for the different preparation methods for most of the shown elements. Nevertheless, this does not hold for all the analysed elements (e. g. S, Se).

Comparing sections and homogenates, the following differences are observed: for $\mathrm{H} I$ the calcium content of the sections was much higher (S I 4 times, S IV 1.5 times). Sr could only be detected within embedded samples (S I $0.8 \cdot 10^{-6}$, S IV 0.01-0.1 $10^{-6}$ ), in homogenates it was below the detection limit being $0.01-0.02 \cdot 10^{-6}$.

A far lower content within the sections compared to the homogenised samples has been found for potassium (S I near zero, S IV $1 / 20$ ), rubidium (S I below the detection limit, S IV 1/25) and Cl. A weak, but clear decrease of $\mathrm{P}, \mathrm{Zn}, \mathrm{Se}, \mathrm{Br}$ and Mo was observed in these groups.

The most remarkable difference between homogenised biopsy specimens and larger pieces of tissue was an increased content of $\mathrm{Cl}$ and $\mathrm{Br}$ within the biopsy samples, On the other hand, the potassium content was reduced by about $35 \%$ in these groups. Increase of the lead content was seen for both homogenates (H II, H III) taken with steel needles. A strikingly increased content of $\mathrm{Ni}$ and $\mathrm{Cr}$ was only found in homogenized biopsy specimens taken with single use puncture needles (H IIII).

1) National Bureau of Standards, Washington, USA.
In general, homogenized samples of biopsies showed a higher standard deviation than those of larger pieces of tissue.

\section{Discussion}

In order to find out the effects of paraffin-embedding and of sampling by puncture needles, the results obtained for the homogenates $\mathrm{HI}$ are used as reference values, supposing them to represent best the real values of the analysed liver tissue. The comparison of different preparation procedures does not answer the question as to how much the results of trace element analysis of this group $\mathrm{H}$ I differ by positive or negative contamination from the original content of the analysed tissue. These contaminations should not exceed $10 \%$, except for $\mathrm{Cr}$ and $\mathrm{Ni}$. As statistical factors they otherwise should enlarge the standard deviations, which are about $5-10 \%$, except for $\mathrm{Cr}$ and $\mathrm{Ni}$.

\section{Effects of paraffin-embedding}

Significant differences are found between the element content of the homogenates $\mathrm{H} \mathrm{I}-\mathrm{III}$ and the sections S I-IV. These differences can be explained as contaminations by the paraffin, and/or elution of some elements by contact of the tissue with the various fixing solutions or with the paraffin.

$\mathrm{Ca}$ and $\mathrm{Sr}$ presumably arise as contaminations from the paraffin as we observed for $\mathrm{Ca}$ in a former investigation (4). Comparing paraffin-embedded sections, frozen sections and tissue homogenates, Jundt et al. (1) did not find any change of Ca-concentration within the sections, probably through using paraffin of higher purity than ours.

The relative decrease of some elements $(\mathrm{K}, \mathrm{Rb}, \mathrm{Zn}, \mathrm{Se})$ correlates well with the subcellular distribution where $\mathrm{Zn}, \mathrm{Se}, \mathrm{Rb}(4)$ and $\mathrm{K}(6)$ were found mainly within the soluble fraction of rat liver cells. This favours the elution of these elements. Our earlier observations (4) (large decrease of $\mathrm{K}$ and $\mathrm{Rb}$, small decrease of Mo and P) are verified, as are the results of Jundt et al. (1), who found a reduced content of potassium, lead, bromine and rubidium in paraffin sections; Kubo et al. (2) observed similar decreases for $\mathrm{K}, \mathrm{Zn}, \mathrm{Br}$ and $\mathrm{Cl}$.

As expected, all these effects are far more pronounced for the embedded biopsy specimens than for the larger tissue sections, because the tissue gets more impregnated with the fixing solutions, and their relatively larger surface causes more contact with the paraffin. For the larger pieces of tissue, however, these effects arise mainly from the marginal zones. Therefore, the influence is less if the proton beam is focussed on the center of the section.

The effects discussed above are more distinct for the biopsies embedded by routine embedding than by manual embedding. 

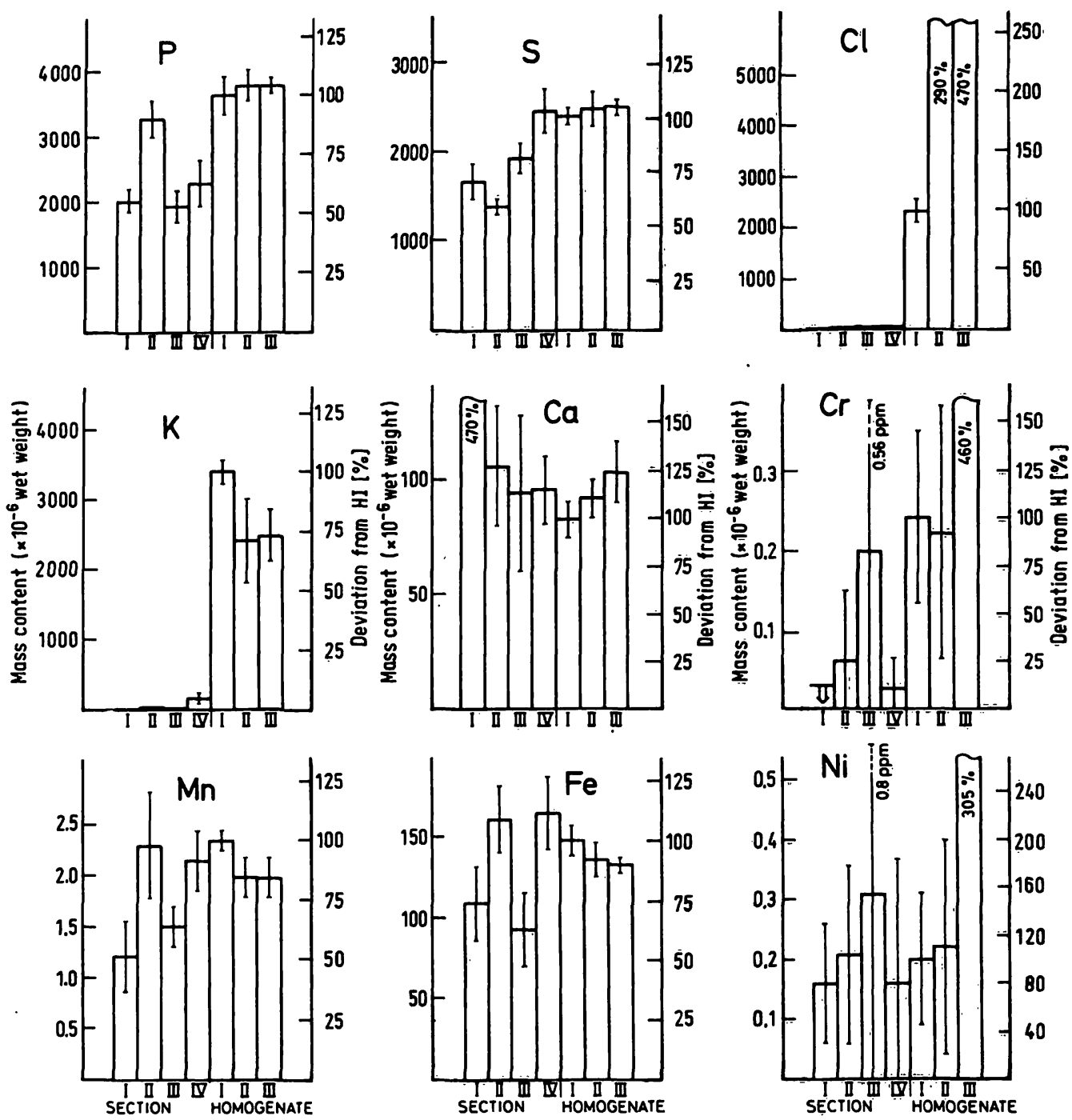

Fig. 2a. Mean value and standard deviation of element contents $(n=8$ for each group) given for the different preparation methods (see table 1)

left scale: mass content in $10^{-6}$ wet weight (dry weight content is 3.86 times the wet weight value) right scale: deviation (in percent) from the value of the homogenate $\mathrm{H} I$.

For the elements $\mathrm{P}, \mathrm{Mn}, \mathrm{Fe}, \mathrm{Zn}, \mathrm{Se}, \mathrm{Mo}$ the elution effect can be roughly corrected for. Therefore, it seems to be possible to compare at least the relative contents of these elements as shown in figure 3. Concerning the absolute contents, the larger tissue sections are sufficiently reliable to be used for the analysis of the elements $\mathrm{S}, \mathrm{Ca}$, $\mathrm{Mn}, \mathrm{Fe}, \mathrm{Cu}, \mathrm{Zn}, \mathrm{Se}, \mathrm{Mo}, \mathrm{Cd}$ and partially $\mathrm{Br}$ and $\mathrm{Pb}$, especially if embedded with special precautions ("manual embedding"). This is valid, providing one is dealing with individual variations in the trace element content (9), which allow conclusions concerning pathological changes only when the changes are very large. Nevertheless, homogenised samples in either event are more suited for multi element analysis than paraffin-embedded sections.
It should be emphasized that it was not intended to develop a special paraffin-embedding procedure, which allows accurate trace element analysis, but to check the reliability of commonly used embedding procedures for trace element analysis.

\section{Effects of sampling by steel needles}

Any changes in the element content due to sampling by steel needles ought to be found by comparing $\mathrm{H} I$ and the groups, H II and H III. Values of S II and S III in relation to $S$ IV can also be taken into account, paying attention to differences in sample size and the resulting problems. 

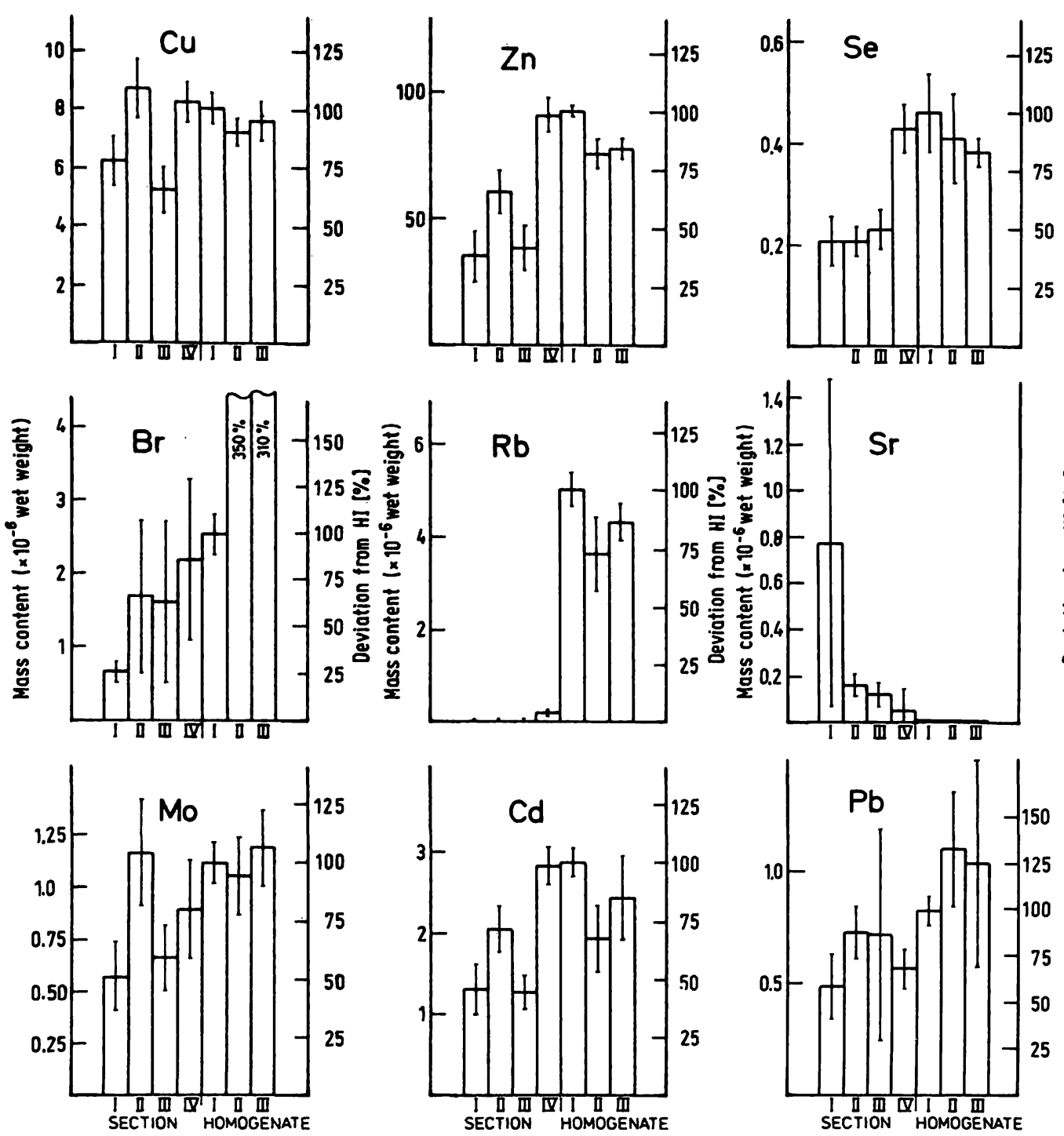

Fig. 2 b. Mean value and standard deviation of element contents ( $n=8$ for each group) given for the different preparation methods (see table 1)

left scale: mass content in $10^{-6}$ wet weight (dry weight content is 3.86 times the wet weight value) right scale: deviation (in percent) from the value of the homogenate $\mathrm{H} I$.

The main differences between homogenised samples of tissue pieces and biopsies apparently are not due to the needle itself: as for routine liver biopsies, an isotonic solution has to be applied to squirt the tissue out of the needle. The $9 \mathrm{~g} / \mathrm{l} \mathrm{NaCl}$ solution, which has been chosen, explains the higher chlorine and bromine (due to contamination of the solution) content of these groups. In addition, this rinsing of the tissue cylinders led to an elution of about $35 \%$ of the potassium content.

Compared to the larger pieces of tissue, biopsies taken with a Menghini needle did not show any significant change that could be explained as contamination by the needle itself.

However, contamination with $\mathrm{Cr}$ and $\mathrm{Ni}$ of about $0.05-0.1 \cdot 10^{-6}$ cannot be excluded; this would result in a contamination of $5-10$ times the normal content of liver tissue (Cr $0.0095, \mathrm{Ni} 0.065 \mu \mathrm{g} / \mathrm{g}$ wet weight in 1. c. (3) recalculated from the original data in l. c. (7)). Since the $\mathrm{Ni}$ and $\mathrm{Cr}$ content of the homogenates H I exceeds values published by other authors (7), it is not known whether the contents in this liver were increased or whether the high $\mathrm{Cr}$ and $\mathrm{Ni}$ values are due to contamination. The first explanation, however, seems to be more likely, because in homogenised samples of other livers we observed $\mathrm{Cr}$ and $\mathrm{Ni}$ values near or below the limit of detection (about $0.03 \cdot 10^{-6}$ ). In contrast to the latter, biopsy needles for single use distinctly increase the mean value and variation of the $\mathrm{Cr}$ and $\mathrm{Ni}$ content. Presumably, the Menghini needles had been wetted during long term use in clinical practice resulting in the loss of less metal.

The pronounced trace element contamination in biopsies described by Versieck et al. (3) has not been confirmed. This might be due to the method they used $(3,8)$. 


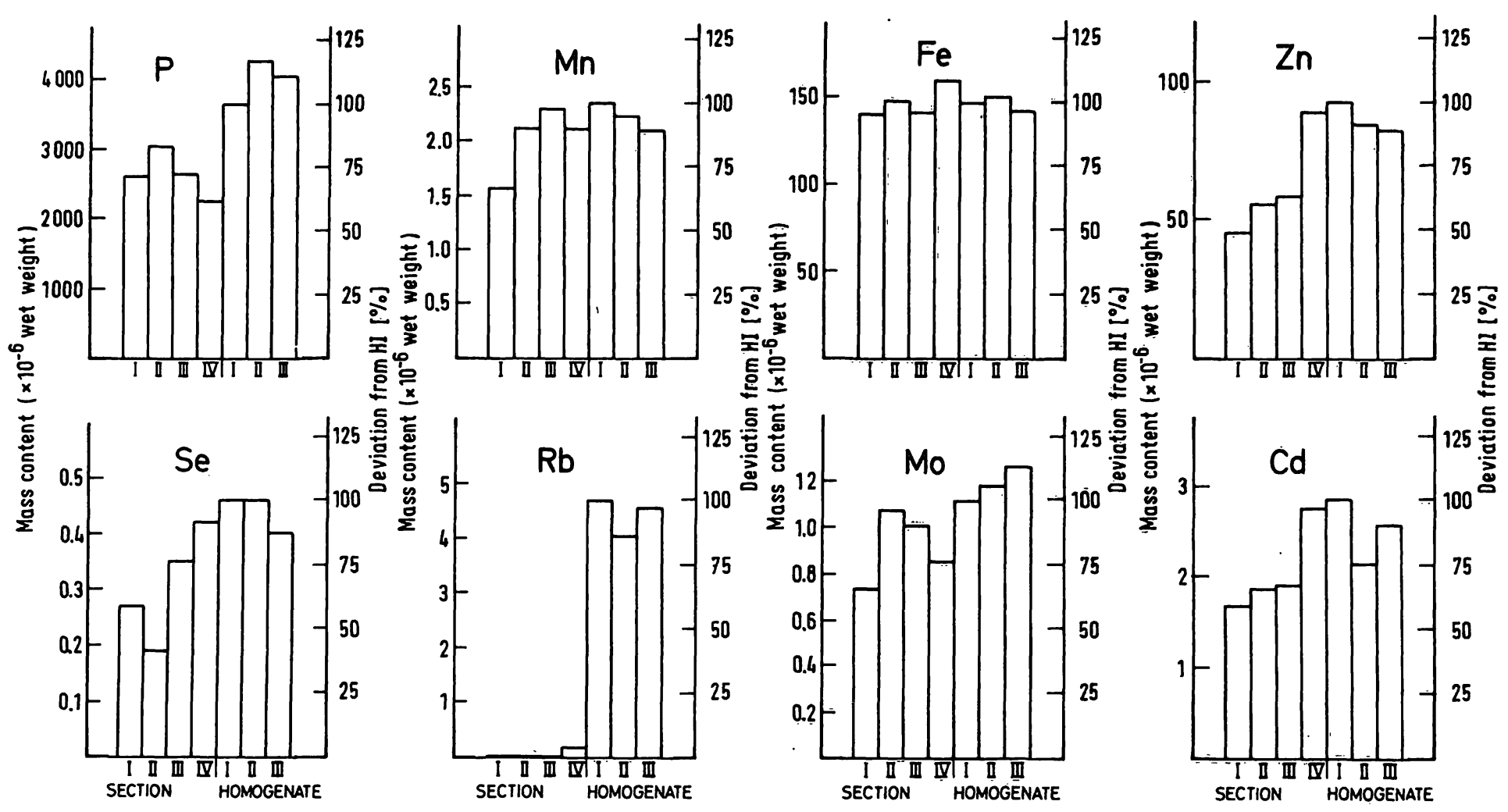

Fig. 3: Comparison of the relative mass content obtained with different preparation methods by normalizing the copper content of S I-S IV and H II, H III to the copper content of H I.

Left scale: mass content (in $10^{-6}$ wet weight) of $\mathrm{H} \mathrm{I}$;

right scale: deviation (in percent) from the value of the homogenate $\mathrm{H} \mathrm{I}$.

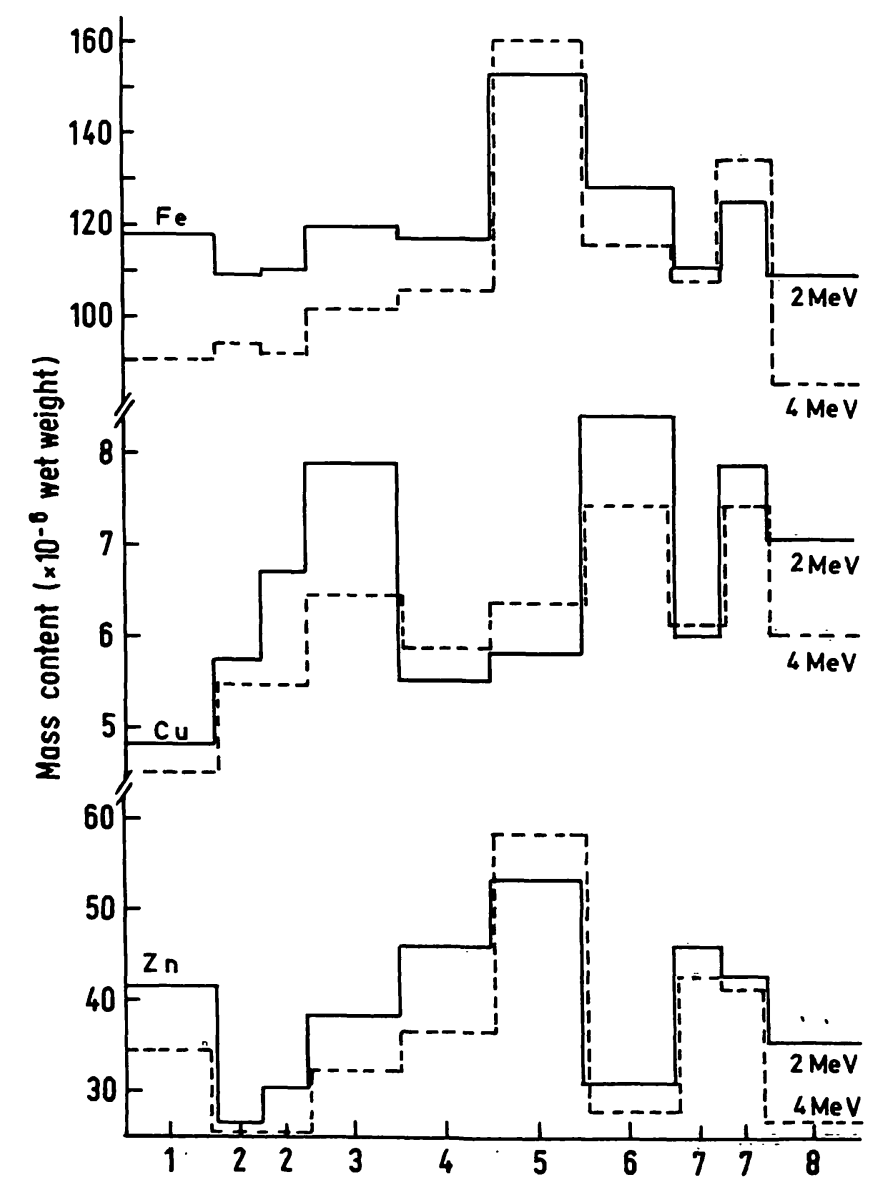

Fig. 4. Correlations $(\mathrm{Fe}, \mathrm{Cu}, \mathrm{Zn}$ ) between the two independent measurements at $2 \mathrm{MeV}$ and $4 \mathrm{MeV}$ proton energy, indicating possible microstructure-effects for samples $\mathrm{S}$ I (biopsy sections).

\section{Effects of small sample size}

The larger variation for sections of biopsy specimens can be explained as a consequence of the microstructure of liver tissue. The needle with an internal diameter of $1.6 \mathrm{~mm}$ can hit mainly the centre of a lobule of the liver or the marginal zones of neighbouring lobules. This could lead to different results in element content. When the two independent measurements at $2 \mathrm{MeV}$ and $4 \mathrm{MeV}$ proton energy for each sample as shown for $\mathrm{Fe}, \mathrm{Cu}$ and $\mathrm{Zn}$ in figure 4 are compared, significant correlations between the two measurements can be seen. This seems to verify the assumption discussed above.

Similarly, the increase of the standard deviation of the lead content in the biopsy samples (sections and homogenates) might be an effect of both sample size and local variation of the lead content within the liver (see fig. 1). Large local variations of lead within the liver have been found (10).

This investigation was supported by the Deutsche Forschungsgemeinschaft. It contains major parts of the thesis of $B$. Meinel. 


\section{References}

1. Jundt, F. C., Purser, K. H., Kubo, H. \& Schenk, E. A. (1974), J. Histochem. Cy tochem. 221, 1-6.

2. Kubo, H., Hashimoto, S., Ishibashi, A., Chiba, R. \& Nakamura, H. (1975), In: Trace substances in environmental health, (D. D. Hamphill, ed.) IX. Columbia, Univ. of Missouri 1975.

3. Versieck, J., Speecke, A., Hoste, J. \& Barbier, F. (1973), Clin. Chem. 19, 472-475.

4. Hasselmann, I., Koenig, W., Richter, F. W., Steiner, U., Wätjen, U., Bode, J. Ch. \& Ohta, W. (1977), Nucl. Instrum. Methods 142,163-169.

5. Scheer, J., Voet, L., Wätjen, U., Koenig, W., Richter, F. W. \& Steiner, U. (1977), Nucl. Instrum. Methods 142, 333-338.

6. Thiers, R. E. \& Vallee, B. E. (1957), J. Biol. Chem. 226, 911-920.

7. Tipton, I. H. \& Cook, M. J. (1963), Health Phys. 9, 103145.

8. Versieck, J., Barbier, F., Dickson, E. R., McCall, J. T. \& Backenstoß, A. H. (1975), Gastroenterology 69, 279-280.

9. Perry, H. M., Tipton, I. H., Schroeder, H. A. \& Cook, M. J. (1962), J. Lab. Clin. Med. 60, 245-253.

10. Koenig, W., Richter, F. W., Meinel, B. \& Bode, J. Ch. (1979), this J. 17, 23-27.

Prof. Dr. F. W. Richter

FB Physik der Universität

Renthof 5

D-3550 Marburg

Prof. Dr. med. J. Ch. Bode

Medizinische Klinik der Universität

Emil-Mannkopffstraße 1

D-3550 Marburg 
. 